\title{
Enzyme changes in malnutrition
}

\author{
J. C. WATERLOW \\ From the Department of Human Nutrition, London School of Hygiene and Tropical Medicine
}

Since this symposium is concerned with enzymes in medicine, I shall consider only the work that has been done in human malnutrition. It would be impossible to deal with the very large literature on enzyme changes in animals under different dietary conditions. I shall also confine myself to work which is related to protein and calorie deficiency because this is the field with which I am familiar, although since most of the B-complex vitamins act as cofactors for one or more enzymes of intermediary metabolism or of the respiratory chain, certain enzyme measurements may be of value in the diagnosis of vitamin deficiencies, eg, the measurement of red-cell transketolase (EC 2.2.1.1.) in thiamine deficiency and of glutathione reductase (EC 1.6.4.2.) in riboflavin deficiency.

Studies on enzyme changes in human subjects with protein-calorie malnutrition have, broadly speaking, followed three paths, with different aims and different underlying assumptions. These may be summarized as follows: (1) the study of enzymes as 'protein markers' to give information about the functional state of protein metabolism in the body as a whole, or in one tissue or organ; (2) the search for increases in enzyme concentration in blood or urine as evidence of cell damage; (3) the study of enzyme changes in tissues, in order to identify the underlying biochemical lesion in any given state of malnutrition.

\section{Serum Enzymes as an Index of Protein Deficiency}

Twenty years ago it was thought, perhaps naively, that, since enzymes are proteins, a fall in the amount of dietary protein might be reflected in a reduction in the amounts of enzymes in blood or tissues, and hence that measurements of enzyme activity might provide a useful tool for assessing the state of protein nutrition. It seemed also that, since many enzymes which appear in the serum are tissue-specific, their activity might reflect the functional state of the organ from which they are derived.

By 1950 it had been recognized that one of the cardinal biochemical changes in protein-calorie malnutrition is a reduction in the concentration of plasma albumin which is synthesized in the liver. The first enzyme to be studied from a nutritional standpoint was also a protein derived from the liver, namely, cholinesterase (EC 3.1.1.8). At about the same time McCance and his colleagues working on adults in Germany (Hutchinson, McCance, and Widdowson, 1951) and I working on infants in West Africa (Waterlow, 1950) showed that in malnutrition plasma cholinesterase levels followed fairly closely those of albumin. In the malnourished infants the activity of this enzyme was reduced in the liver as well as in the plasma.

In the next few years, measurements of this kind were extended to a number of other enzymes which can be detected in the plasma, eg, alkaline phosphatase (EC 3.1.3.1), in children largely derived from bone, lipase (EC 3.1.1.3) and amylase (EC 3.2.1.1) from the pancreas, and carboxylase (EC 3.1.1.1) which is another liver enzyme. As Table I shows, in general the activities in serum or plasma are low in children with established protein malnutrition.

It is interesting that, when rickets is accompanied by protein deficiency, alkaline phosphatase levels are low instead of high; in fact, the florid signs of rickets do not appear until protein is given and the child begins to grow. The low levels of amylase and lipase in serum are accompanied by a reduced output of pancreatic enzymes into the gut (Thompson and Trowell, 1952). However, there appears to be an adequate functional reserve, since the digestion of carbohydrate and protein is not impaired, although there may be some reduction in the splitting of fat. Similarly the levels of the enzymes produced in the liver may be low without any other evidence of abnormal liver function. It seems, therefore, that these reductions in the activity of enzymes in the serum may be regarded as metabolic effects which precede functional impairment. Therefore they might be regarded as sensitive indicators of protein malnutrition, but we do not really know whether they are sensitive enough to indicate early malnutrition before other clinical or biochemical changes develop. The only studies on this point appear to be those of Arroyave, Feldman, and Scrimshaw (1958) and of 


\begin{tabular}{|c|c|c|}
\hline Enzyme & Activity in Serum or Plasma & Authors \\
\hline Cholinesterase & Reduced & $\begin{array}{l}\text { Waterlow (1950) } \\
\text { Dean and Schwatrz (1953) } \\
\text { Baron (1960) } \\
\text { Edozien (1961) } \\
\text { Schendel et al (1962) } \\
\text { Montgomery (1963) }\end{array}$ \\
\hline Alkaline phosphatase & Reduced & $\begin{array}{l}\text { Dean and Schwartz (1953) } \\
\text { Edozien (1961) } \\
\text { Sandstead } \text { et al (1965) }\end{array}$ \\
\hline Carboxylase esterase (nonspecific) & $\begin{array}{l}\text { Reduced in kwashiorkor } \\
\text { Slightly reduced in marasmus }\end{array}$ & $\begin{array}{l}\text { Dean and Schwartz (1953) } \\
\text { Srikantia et al (1964) } \\
\text { Srikantia et al (1964) }\end{array}$ \\
\hline Amylase & $\begin{array}{l}\text { Reduced in kwashiorkor } \\
\text { Unchanged in marasmus }\end{array}$ & $\begin{array}{l}\text { Dean and Schwartz (1953) } \\
\text { Edozien (1961) } \\
\text { Srikantia et al (1964) } \\
\text { Srikantia et al (1964) }\end{array}$ \\
\hline Lipase & $\begin{array}{l}\text { Reduced in kwashiorkor; unchanged in } \\
\text { marasmus }\end{array}$ & $\begin{array}{l}\text { Srikantia et al (1964) } \\
\text { Srikantia et al (1964) }\end{array}$ \\
\hline Creatine kinase & $\begin{array}{l}\text { Reduced in kwashiorkor; less reduced and } \\
\text { sometimes elevated in marasmus }\end{array}$ & Balmer and Rutishauser (1967) \\
\hline
\end{tabular}

Behar, Arroyave, Flores, and Scrimshaw (1960) who found that plasma cholinesterase levels in children from poor families, who might be regarded as marginally malnourished, did not differ from those in better fed controls.

Serum creatine kinase (EC 2.7.3.2) is the latest addition to the list of tissue specific enzymes found to be reduced in malnutrition. The low levels found in children with kwashiorkor were thought by Balmer and Rutishauser (1967) to reflect the reduction in muscle mass. This was confirmed experimentally by Reindorp (1970) who showed that in rats deprived of protein there was a close relationship between serum creatine kinase activity, creatinine output, and muscle weight. In marasmus Balmer and Rutishauser (1967) found that creatine kinase levels tended to be higher than in kwashiorkor, and some very high values were found just before death in fatal cases. They concluded that when there is active breakdown of muscle tissue, and perhaps when muscle protein is being catabolized to provide energy, there may be an increased release of creatine kinase into the blood stream.

In fact most of the enzymes listed in Table I are reduced less in marasmus than in kwashiorkor, and serum albumin behaves in the same way. The hypothesis usually advanced to explain this is that when protein catabolism, particularly in muscle (Millward, 1970), is increased to make good a calorie deficiency, more amino acids are available for the synthesis of essential proteins such as enzymes. Thus the activity of the enzymes in serum is the resultant of two opposing factors, protein deficiency tending to lower the levels and calorie deficien tending to increase them. This makes interpretation of serum levels difficult.

A further difficulty about the use of cregtio kinase as an index of muscle protein depletion is hiat serial measurements showed very large fluctuation, probably due to infection or to physical act it (Reindorp, 1970). It seems likely that the levels other enzymes in the serum will also be affected non-nutritional factors, but this point has not, to nu knowledge, been adequately explored.

A general criticism of this whole approach is tha् it is largely empirical. There does not seem to be any particular reason why some enzymes but not others appear in serum in detectable amounts, and ome cannot draw any general conclusions from the behaviour of these particular enzyme proteins. now know that the same dietary stimulus may alter the activity of different enzymes in different, even in opposite, ways. In the liver, protein deficiengy causes a reduction in the rate of synthesis of albumin, and presumably also of cholinesterase, but this doos not apply to liver proteins as a whole (Waterlow ant Stephen, 1968). There are enzymes in the liver whose activity is extremely sensitive to the level of protein intake, eg, enzymes of amino acid catabolism, su\& as serine dehydratase, (EC 4.2.1.13) the activity of which may change 100-fold with an appropriate stimulus (Fallon, Hackney, and Byrne, 196\%. Unfortunately, serine dehydratase has not been detected in the blood, so that advantage cannot be taken of the sensitivity with which it responds to the level of protein intake. 
For these reasons, the measurement of enzymes in serum has not in practice proved particularly useful, either for assessing the severity of protein malnutrition or for detecting an impending deficiency state. However, further work may well reverse this judgment, as the field has not been fully explored.

\section{Leakage of Enzymes from Tissues}

We tend to think of protein-calorie malnutrition as causing a loss of cell substance which is reversed when food is provided. However, a starved cell must eventually die. When this occurs it might be expected that enzymes will leak into the serum just as in other diseases where there is cell destruction. In kwashiorkor fatty infiltration of the liver is a common feature and may be so severe that the child develops jaundice and dies, probably of hepatic failure. The microscopical appearance suggests that there may be very little circulation of blood through these livers, and it is not surprising if there is extensive hepatic cell damage.

Table II summarizes the results of a number of studies which have been made of this point. In

\begin{tabular}{|c|c|c|}
\hline Enzyme & $\begin{array}{l}\text { Activity in } \\
\text { Serum or Plasma }\end{array}$ & Authors \\
\hline Aminotransferases & Increased & $\begin{array}{l}\text { Baron (1960) } \\
\text { Edozien (1961) } \\
\text { McLean (1962) }\end{array}$ \\
\hline $\begin{array}{l}\text { Isocitrate dehydrogenase } \\
\text { (EC 1.1.1.42) } \\
\text { Lactate dehydrogenase } \\
\text { (EC 1.1.1.27) }\end{array}$ & $\begin{array}{l}\text { Unchanged } \\
\text { Increased } \\
\text { Increased }\end{array}$ & $\begin{array}{l}\text { Smith (1962) } \\
\text { McLean (1962) } \\
\text { Sandstead et al (1965) }\end{array}$ \\
\hline
\end{tabular}

Table II Some enzyme changes in protein-calorie malnutrition which may indicate cell damage

general, raised enzyme levels have been found in the serum of patients with protein malnutrition. The findings of McLean (1966) are of particular interest. He showed that the activity of alanine aminotransferase (EC 2.6.1.1) in serum was increased, and that the greater the increase the greater was the mortality (Table III). In the liver, however, the opposite was found, namely, a decrease in the aminotransferase, which was more marked in the more severe cases (Table IV). Leakage no doubt plays a part in this, but McLean showed that there is also an adaptive fall of enzyme synthesis in response to protein deficiency, exactly like that produced experimentally by low protein diets in rats (Rosen, Roberts, and Nichol, 1959; Muramatsu and Ashida, 1962). Presumably this adaptive change must tend to minimize the increase in serum aminotransferase produced by cell damage.

\begin{tabular}{llll}
\hline Serum AlAT & No. of Patients & No. of Deaths & Mortality (\%) \\
\hline $0-100$ & 63 & 0 & 0 \\
$101-200$ & 44 & 3 & 7 \\
$201-250$ & 8 & 2 & 25 \\
$251-500$ & 18 & 5 & 28 \\
$501 \times$ & 4 & 4 & 100 \\
\hline
\end{tabular}

Table III Serum alanine aminotransferase (AlAT) on admission and mortality rate in malnourished children ${ }^{1}$

${ }^{1}$ In normal Jamaican infants; GPT $=45 \pm 24$ (McLean, 1966).

\begin{tabular}{|c|c|c|}
\hline Biopsy Taken & $\begin{array}{l}\text { No. of } \\
\text { Biopsies }\end{array}$ & $\begin{array}{l}\text { AlAT (units) } \\
\text { mg protein; } \\
\text { mean }+S D \text { ) }\end{array}$ \\
\hline $\begin{array}{l}\text { From Dead Patients } \\
\text { Within } 30 \text { minutes after death }\end{array}$ & 11 & $1.8 \pm 0.5$ \\
\hline $\begin{array}{l}\text { From Living Patients } \\
\text { 2-3 days after admission } \\
\text { 6-14 days after admission } \\
\text { 15-20 days after admission } \\
>40 \text { days after admission } \\
\text { After low protein diet given two weeks } \\
\text { after recovery } \\
\text { From Adults, Well Nourished and without } \\
\text { Liver Disease }\end{array}$ & $\begin{array}{r}8 \\
8 \\
4 \\
15 \\
7 \\
7 \\
6\end{array}$ & $\begin{aligned} 3 \cdot 4 & \pm 2 \cdot 1 \\
4 \cdot 3 & \pm 2 \cdot 1 \\
10 \cdot 1 & \pm 2 \cdot 2 \\
11 \cdot 8 & \pm 2 \cdot 2 \\
6 \cdot 5 & \pm 1 \cdot 2 \\
12 \cdot 5 & \pm 2 \cdot 5\end{aligned}$ \\
\hline
\end{tabular}

Table IV Alanine aminotransferase (AlAT) in liver biopsies from malnourished children and adult controls (McLean, 1966)

Ittyerah, Dumm, and Bachhawat (1967) and Begum and Ittyerah (1970) found that in India children with kwashiorkor had raised serum levels and increased urinary excretion of the lysosomal enzyme arylsulphatase (EC 3.1.6.1), and suggested that there is a specific lesion of the lysosomes. However, in the malnourished patients there was no change in other lysosomal enzymes, $\beta$-glucuronidase (EC 3.2.1.31) and acid phosphatase (EC 3.1.3.2). Moreover, the excretion of arylsulphatase was greatly increased by infection, so that the effect was not specific for malnutrition.

It seems probable that these increases in serum and urinary enzymes are relatively late events in the progression of malnutrition; they may be of value for prognosis, but not for assessment or diagnosis in the early stages.

\section{Cellular Enzymes: the Search for Biochemical Lesions}

Measurements of enzymes after death are not likely to be of much value, and therefore for work on tissue enzymes we are confined to biopsies or white blood cells, and this in turn means that micromethods have to be used. These difficulties have limited both the scale and the scope of what has been achieved.

In the decade from 1950 to 1960 , several groups studied a range of liver enzymes in malnourished 
infants. The results have been reviewed before (Waterlow, 1959; Waterlow, Cravioto, and Stephen, 1960) and need not be repeated here. It is enough to recall that the enzymes were selected largely because it was possible to measure them by micromethods and that, although some were reduced, the majority were well preserved even in severe malnutrition.

This work was entirely empirical; later work was at least guided by some more definite objective or hypothesis. For example, our studies of oxidative phosphorylation in the liver (Waterlow, 1961) were based on the idea that protein deficiency might interfere with an overall reaction which depended upon the structural integrity of subcellular elements, even though all the individual enzymes might be well preserved. In fact, in malnourished infants oxidative phosphorylation was reduced in liver homogenates and it was also less stable than in controls. Clearly a defect in oxidative phosphorylation would be a very serious matter; however in interpreting these results it was difficult to separate artefacts caused by excess fat in some of the malnourished livers.

Metcoff, Frenk, Yoshida, Torres Pinedo, Kaiser, and Hansen (1966) have made extensive studies in severely malnourished infants of enzymes and intermediates of carbohydrate metabolism in muscle, with the aim of explaining the mechanism of the disturbances in electrolyte balance which often prove fatal. Their salient finding in the present context was a decrease in pyruvate kinase (EC 2.7.1.40) activity. The results are consistent with the idea that there is a failure of the energy supply for the 'sodium pump', so that sodium accumulates in the cell.

Children with protein-calorie malnutrition often present the paradoxical condition of hypoglycaemia with reduced glucose tolerance. Alleyne and Scullard (1970) investigated the possibility that the low blood sugar might be caused by a reduction in hepatic glucose 6-phosphatase (EC 3.1.3.9). In fact, however, the activity of this enzyme was found to be increased when the children were malnourished, and fell on recovery. In a later study, Alleyne, Flores, Trust, and Waterlow (1971) obtained muscle samples by punch biopsy and tested the peripheral utilization of glucose by measurements of glycolysis in homogenates. With several substrates glycolysis was reduced in both malnourished and recovered children when compared with children who had never been malnourished. In another series insulin secretion also remained low long after clinical recovery had occurred (James and Coore, 1970). These findings suggest that malnutrition may cause long-lasting, possibly even permanent, metabolic changes.

A final example of the application of enzyme measurements to problems of human nutrition is our study of adaptive changes in enzymes of amino acid metabolism in the liver (Stephen and Waterlöw, 1968). As the children recovered, the activity of the amino acid synthetic system fell, and that of argininosuccinate lyase (EC 4.3.2.1), an enzyme of the urea cycle, rose. Thus it appeared that in the malnourished state adaptations had occurred which would reduce the catabolism of amino-acids to ucea and promote their uptake into protein.

\section{Conclusion}

क

The ultimate practical objective of the enzyme studies which have been described is to help in the prevention of protein-calorie malnutrition. It $\vec{\omega} s$ often supposed that this is a practical problem $\AA_{0}$ which new scientific knowledge is not needed. Trat is a superficial view. We are faced with the possibility that 'marginal malnutrition' in childhood may cause a permanent handicap throughout life, and yet we cannot recognize or define this 'marginal malnutrition' with any precision. This is not place to discuss the semantics of what is meant by the phrase. The point on which I wish to end is that progress depends on a better understanding of the processes of nutritional adaptation, and of when afld why they break down. Enzyme changes must play a fundamental part in these processes, and this is the justification for the work which has been summafized here.

\section{References}

Alleyne, G. A. O., and Scullard, G. H. (1969). Alterations in car $\overline{8}$ hydrate metabolism in Jamaican children with severe malnutrition. Clin. Sci., 37, 631-642.

Alleyne, G. A. O., Flores, H., Trust, P. M., and Waterlow, J. (1971). Further studies on carbohydrate metabolism in inf tile malnutrition. J. Physiol. (Lond.), 213, 30P.

Arroyave, G., Feldman, R., and Scrimshaw, N. S. (1958). Serum cholinesterase levels of Central American children in relation to nutritional status. Amer. J. clin. Nutr., 6, 164-168.

Balmer, S. E., and Rutishauser, I. H. E. (1968). Serum creatine kinase in malnutrition. J. Pediat., 73, 783-787.

Baron, D. N. (1960). Serum transaminases and isocitric dehydrogenase in kwashiorkor. J. clin. Path., 13, 252-255.

Begum, A., and Ittyerah, T. R. (1970). Arylsulfatase and B-glucuron. dase activity in serum in kwashiorkor. Clin. chim. Acta, 28, 263-268.

Béhar, M., Arroyave, G., Flores, M., and Scrimshaw, N. S. (196@). The nutritional status of children of pre-school age in the Guatemalan community of Amatitlan. 2. Comparison $\mathrm{Jf}$ dietary clinical and biochemical findings. Brit. J. Nutr., 12 217-230.

Dean, R. F. A., and Schwartz, R. (1953). The serum chemistry in uncomplicated kwashiorkor. Brit. J. Nutr., 7, 131-147.

Edozien, J. C. (1961). Enzymes in serum in kwashiorkor. Pediatrif, 27, 325-333.

Fallon, H. J., Hackney, E. J., and Byrne, W. L. (1966). Serine bi synthesis in rat liver. Regulation of enzyme concentration dietary factors. J. biol. Chem., 241, 4157-4167.

Hutchinson, A. O., McCance, R. A., and Widdowson, E. M. (1958. Serum cholinesterases. Spec. Rep. Ser. med. Res. Coun. (Londd, 275, 216-225

Ittyerah, T. R., Dumm, M. E., and Bachhawat, B. K. (1967). Urina excretion of lysosomal arylsulfatases in kwashiorkor. Clit. chim. Acta, 17, $405-414$.

James, W. P. T., and Coore, H. G. (1970). Persistent impairment insulin and glucose tolerance after malnutrition. Amer. J. clist: Nutr., 23, 386-389. 
McLean, A. E. M. (1962). Hepatic failure in malnutrition. Lancet, 2, 1292-1294.

McLean, A. E. M. (1966). Enzyme activity in the liver and serum of malnourished children in Jamaica. Clin. Sci., 30, 129-137.

Metcoff, J., Frenk, S., Yoshida, T., Torres Pinedo, R., Kaiser, E., and Hansen, J. D. L. (1966). Cell composition and metabolism in kwashiorkor (severe protein-calorie malnutrition in children). Medicine (Baltimore), 45, 365-390.

Millward, D. J. (1970). Protein turnover in skeletal muscle. II. The effect of starvation and a protein-free diet on the synthesis and catabolism of skeletal muscle proteins in comparison to liver. Clin. Sci., 39, 591-603.

Montgomery, R.D. (1963). The relation of oedema to serum protein and pseudocholinesterase levels in the malnourished infant. Arch. Dis. Childh., 38, 343-348.

Muramatsu, K., and Ashida, K. (1962). Effect of dietary protein level on growth and liver enzyme activities of rats. J. Nutr., 76, 143-150.

Reindorp, S. (1970). Changes in skeletal and cardiac muscle caused by prolonged protein-calorie malnutrition in relation to serum creatine kinase activity and the urinary excretion of creatinine. Ph.D. Thesis, University of London.

Rosen, F., Roberts, N. R., and Nichol, C. A. (1959). Glucocorticosteroids and transaminase activity. I. Increased activity of glutamic-pyruvic transaminase in four conditions associated with gluconeohenesis. J. biol. Chem., 234, 476-480.

Sandstead, H. H., Shukry, A. S., Prasad, A. S., Gabr, M. K., El Hifney, A., Mokhtar, N., and Darby, W. J. (1965). Kwashiorkor in Egypt. I. Clinical and biochemical studies, with special reference to plasma zinc and serum lastic dehydrogenase. Amer. J. clin. Nutr., 17, 15-26.

Schendel, H. E., Hansen, J. D. L., and Brosk, J. F. (1962). The biochemical assessment of protein nutritional status. S. Afr. J. Lab. clin. Med., 9, 23-25.

Smith, C. E. (1962). Serum transaminases in kwashiorkor. J. Pediat., 61, 617-619.

Srikantia, S. G., Jacob, C. M., and Reddy, V. (1964). Serum enzyme levels in protein-calorie malnutrition. Amer. J. Dis. Child., 107, 256-259.

Stephen, J. M. L., and Waterlow, J. C. (1968). Effect of malnutrition on activity of two enzymes concerned with aminoacid metabolism in human liver. Lancet, 1, 118-119.

Thompson, M. D., and Trowell, H. C. (1952). Pancreatic enzyme activity in duodenal contents of children with a type of kwashiorkor. Lancet, 1, 1031-1035.

Waterlow, J. C. (1950). Liver choline-esterase in malnourished infants. Lancet, 1, 908-909.

Waterlow, J. C. (1959). Protein nutrition and enzyme changes in man. Fed. Proc., 18, 1143-1155.

Waterlow, J. C. (1961). Oxidative phosphorylation in the livers of normal and malnourished human infants. Proc. roy. Soc. B., $155,96-114$.

Waterlow, J. C., Cravioto, J., and Stephen, J. M. L. (1960). Protein malnutrition in man. Advanc. Protein. Chem., 15, 131-238.

Waterlow, J. C., and Stephen, J. M. L. (1968). The effect of low protein diets on the turnover rates of serum, liver and muscle proteins in the rat, measured by continuous infusion of $\mathrm{L}-\left({ }^{14} \mathrm{C}\right)$ lysine. Clin. Sci., 35, 287-305. 